Research article

\title{
Organoleptic quality of Ethiopian Arabica coffee deteriorates with increasing intensity of coffee forest management
}

\author{
L. Geeraert ${ }^{\mathrm{a}, *, 1}$, G. Berecha ${ }^{\mathrm{b}, 1}$, O. Honnay ${ }^{\mathrm{a}}$, R. Aerts ${ }^{\mathrm{a}, \mathrm{c}}$ \\ a Plant Conservation and Population Biology, University of Leuven, Kasteelpark Arenberg 31-2435, BE-3001 Leuven, Belgium \\ ${ }^{\mathrm{b}}$ Department of Horticulture and Plant Science, Jimma University, P.O. Box 378, Jimma, Ethiopia \\ ${ }^{c}$ Division Forest, Nature and Landscape, University of Leuven, Celestijnenlaan 200E-2411, BE-3001 Leuven, Belgium
}

\section{A R T I C L E I N F O}

\section{Keywords:}

Afromontane forest

Agroforestry

Coffea arabica

Crop wild relative

Cup quality

\begin{abstract}
A B S T R A C T
Arabica coffee (Coffea arabica L.) grows naturally as an understory shrub in the moist evergreen montane forests of Southwest Ethiopia. In response to an increasing local human population pressure and a growing coffee demand on the world market, coffee producing forests are increasingly managed to boost coffee yield. Here we compared organoleptic coffee quality between natural coffee producing forests, large coffee agroforests, and small coffee agroforests. Accounting for variability in Arabica coffee genotype and environment, we found that blind consensus scores, given by a panel of certified Q-Grade cuppers, were negatively affected by increasing forest management intensity. Importantly, only coffee from natural coffee producing forests qualified as specialty coffee following the Specialty Coffee Association of America's standards. We suggest that the most important drivers of deteriorating coffee quality include decreased shade levels and changing micro-climate and biotic interactions. Due to the low yields of coffee in natural coffee producing forests and the lack of quality price premiums, Ethiopian smallholder farmers are inclined to optimize for coffee quantity, rather than for quality, causing a significant challenge for the conservation of Ethiopian natural coffee producing forests.
\end{abstract}

\section{Introduction}

Coffee is economically one of the most important agricultural commodities worldwide, with an estimated 24 billion USD annual trade value (FAO, 2015). Currently, Coffea arabica (Arabica coffee) dominates the global coffee production with a share of $64.5 \%$ (ICO, 2017a) and it is grown in more than 60 countries (ICO, 2017b). The remaining $35.5 \%$ is provided by Coffea canephora (Robusta coffee) (ICO, 2017a), which has a stronger bitterness and higher caffeine content compared to $C$. arabica. The average global coffee consumption continues to grow on average by $1.3 \%$ per year (ICO, 2016). Since the last two decades, a rising global interest developed in specialty coffee, in particular high quality Arabica coffee (Giovannucci et al., 2008). Specialty coffee offers superior organoleptic qualities against a price premium. For example, the percentage of adults in the USA drinking specialty coffee on daily basis increased from 14\% in 2001 to $41 \%$ in 2017 (SCAA, 2017a). In 2016 compared to 2015, the global production of Arabica coffee increased by $14.7 \%$ while the production of Robusta coffee decreased by $12.2 \%$ (ICO, 2017a).
Coffea arabica has its center of diversity in the moist evergreen montane forests of Southwest Ethiopia (Anthony et al., 2002). It grows naturally as an understory shrub, under a dense overstory canopy cover in so called natural coffee producing forests, or natural coffee forests (Schmitt et al., 2010). Due to the low light conditions, wild coffee shrubs grow slowly, are thin and tall, and carry few fruits. In response to the increasing global coffee demand, production is boosted through management on two different levels, i.e. on forest level (coffee forest management) and on shrub level (coffee shrub management).

In SW Ethiopia, coffee forest management includes the removal of a significant proportion of the overstory canopy trees and the clearing of all competing understory vegetation (Aerts et al., 2011; Schmitt et al., 2010). A growing amount of Ethiopian natural forests that produce coffee shrubs are being converted to coffee agroforestry systems, while the management of already existing coffee agroforests is being increasingly intensified (Hylander et al., 2013). The changes in forest structure affect the local microclimate, moisture conditions and soil characteristics (Rudel et al., 2005), and these factors are known to affect the bean quality of Arabica coffee. Through the removal of canopy

\footnotetext{
* Corresponding author.

E-mail addresses: lore.geeraert@kuleuven.be (L. Geeraert), gberecha@yahoo.com (G. Berecha), olivier.honnay@kuleuven.be (O. Honnay), raf.aerts@kuleuven.be (R. Aerts).

${ }^{1}$ These authors contributed equally.
} 
trees, the coffee shrubs are exposed to decreased shade levels. Decreased shade levels have been found to deteriorate the coffee bean quality through changes in the biochemical composition of the green beans, caused by increased light conditions (Geromel et al., 2008), increased mean air temperatures (Bertrand et al., 2012; Joët et al., 2010), and an accelerated ripening process of the coffee berries (Geromel et al., 2008; Vaast et al., 2006). Furthermore, a reduced canopy cover and understory vegetation within coffee agroforests result in decreasing accumulation of organic matter (Beer et al., 1998), decreasing relative soil humidity (De Beenhouwer et al., 2015b), increasing soil temperature, and a higher degree of soil erosion and nutrient leaching (Babbar and Zak, 1994). These changes affect soil mineralization processes and soil nutrient availability (Babbar and Zak, 1994; Beer et al., 1998), which are important factors controlling coffee bean biochemical composition and thus, ultimately, coffee beverage quality (Yadessa et al., 2008).

Coffee shrub management in SW Ethiopia mainly includes increasing the density of naturally occurring coffee shrubs and the introduction of locally improved cultivars which are resistant to Coffee Berry Disease (CBD), a fungal disease caused by Colletotrichum kahawae J.M. Waller \& Bridge (Aerts et al., 2013). The CBD-resistant cultivars have been selected for improved disease resistance, while the organoleptic bean quality was not prioritized. Therefore, introduction of CBD resistant varieties, and subsequent hybridization with wild coffee may possibly affect coffee quality (Aerts et al., 2013). In addition, coffee shrub pruning and fruit thinning may influence coffee bean quality through altering the fruit load. Higher fruit loads were found to reduce coffee bean quality due to resource competition among berries during maturation (Bote and Jan 2017; Vaast et al., 2006).

Overall, coffee forest management dramatically boosts short-term coffee yields, from a mere $15 \mathrm{~kg} \mathrm{ha}^{-1}$ in natural coffee forests annually (Schmitt et al., 2010) to 1.7-2.6 metric tonnes ha $^{-1}$ year $^{-1}$ in the most intensively managed agroforests (Aerts et al., 2011). However, prioritizing yield quantity may jeopardize yield quality. Yet, bean quality is economically also very relevant as high quality beans could achieve Specialty Coffee status, a label for superior coffee created by the Specialty Coffee Association of America (SCAA, 2017b). The Specialty Coffee label is based on an evaluation of the organoleptic quality of coffee. Production methods, environmental conditions of the production areas, or trade properties are subjects of sustainable coffee certification schemes such as USDA Organic, Rainforest Alliance, Smithsonian Bird Friendly, Utz Certified or Fair Trade Certified (Mitiku et al., 2018). To evaluate if coffee samples can achieve the Specialty Coffee status, following attributes are evaluated: fragrance and aroma, flavor, aftertaste, acidity, body, balance, sweetness, clean cup, uniformity, overall appreciation, and defects (SCAA, 2015). Quality, not intensity, of each individual attribute is evaluated during a cupping process. Specialty coffees generally command higher prices on the international market (Bacon, 2005), with potential for positive effects on the livelihood of coffee smallholders (Mitiku et al., 2018). Hence, increasing coffee quality may reduce the need for further yield intensification, enabling the conservation of more extensively managed coffee agroforestry systems and natural coffee forests. A recent study showed, however, that certifications and price premiums often support either socio-economic or environmental aspects (Vanderhaegen et al., 2018).

In this study, our objective was to quantify the overall effect of coffee forest management intensity on Arabica coffee bean organoleptic quality. Especially in Ethiopia, where C. arabica has its center of diversity, quantitative information is needed to guide forest management to obtain a balance between yield quality and quantity. To that end, we sampled coffee berries from 20 sites of different forest management intensity in the Jimma region in SW-Ethiopia. Controlling for elevation, soil characteristics and coffee genetic variability, we specifically aimed at identifying the potential to produce specialty coffee under different coffee forest management regimes.

\section{Materials and methods}

\subsection{Study area}

We conducted our research in the highlands of southwestern Ethiopia, in Gera $\left(7^{\circ} 47^{\prime} 40^{\prime \prime} \mathrm{N}, 36^{\circ} 19^{\prime} 36^{\prime \prime} \mathrm{E}\right)$ and Manna $\left(7^{\circ} 43^{\prime} 56.9^{\prime \prime} \mathrm{N}\right.$, $36^{\circ} 44^{\prime} 50.2^{\prime \prime} \mathrm{E}$ ), two districts within the Jimma zone (Oromia region). This zone is one of the major Arabica coffee growing zones in Ethiopia, and part of the Eastern Afromontane Biodiversity Hotspot (Mittermeier et al., 2011). It is also the center of genetic diversity of C. arabica (Anthony et al., 2002). The landscape is a mosaic of natural coffee forests, coffee agroforests, cropland, grazing land, riverine wetland, and human settlement. Natural coffee forests are converted to coffee agroforests through forest management measures that vary in intensity. Average annual temperatures are $26^{\circ} \mathrm{C}$ during daytime and $13{ }^{\circ} \mathrm{C}$ at night. Average annual rainfall is $2007.5 \mathrm{~mm}$.

\subsection{Study design}

We used a stratified design, selecting three different coffee production systems, each representing a different intensity of coffee forest management: (i) natural coffee forest (NCF); (ii) large coffee agroforest (LCA) of more than 200 ha; and (iii) small coffee agroforest (SCA) of less than 26 ha. We randomly established a total of 20 study plots of $20 \times 20 \mathrm{~m}$ (Fig. 1, Table A.1). Seven plots were located in two NCF systems (ca. 25000 ha and ca. 60000 ha) in the Gera district. Six plots were located in one LCA fragment (ca. 250 ha) in the Manna district, east of the Gera district. In the Manna district, we located seven additional plots in six SCA fragments (areas: 1-26 ha).

The NCF system is unmanaged and produces wild Arabica coffee. The canopy within the studied NCF plots consisted of a mixture of broadleaved tree species that were $10-30 \mathrm{~m}$ tall, with emergent trees that can reach a height of $30-40 \mathrm{~m}$. Tree species diversity was high, with an average of eleven different species per $400 \mathrm{~m}^{2}(20 \times 20 \mathrm{~m}$ plots) (Hundera et al., 2013b). Dominant tree species included Syzygium guineense, Prunus africana, Olea welwitschii, Schefflera abyssinica and Ilex mitis (Berecha et al., 2014; Hundera et al., 2013b). The average crown closure (as measured using a spherical densitometer) was $91 \%$ and the crown cover (based on vertical crown projections) was $88 \%$ (Hundera et al., 2013b).

The LCA and SCA systems have been intensively managed in terms of forest management for several decennia. Hence, the difference between coffee agroforests and natural coffee forests is visually clear from the overall forest structure (Fig. 1). All LCA and SCA plots showed clear evidence of tree removal, coffee planting, management of the coffee shrubs, and removal of competing understory vegetation. Herbicides, pesticides, and chemical fertilizers were not used in the studied plots. Forest management typically aims to reduce the natural crown closure while maintaining high crown cover to provide shade and indirect light to the cultivated Arabica coffee shrubs. In the LCA and SCA plots, all emergent trees were removed and the lower canopy layer $(10-20 \mathrm{~m})$ is strongly decreased in density and species richness. The average species richness was four species per $400 \mathrm{~m}^{2}$ (Hundera et al., 2013b). The dominant tree species here included Albizia gummifera, Albizia schimperiana, Croton macrostachyus and Millettia ferruginea (Berecha et al., 2014; Hundera et al., 2013b). The understory shrub layer is usually completely cleared. In both agroforestry systems, the dense coffee shrub layer consists of wild coffee shrubs, transplanted wild coffee shrubs, and planted CBD-resistant cultivars (Aerts et al., 2013). Maintenance of the cultivated coffee shrubs includes pruning, stumping, and removal of epiphytes that grow on the stem and branches. Forest management intensity increased with decreasing size of the agroforestry fragment. Smaller fragments (SCA) were more intensively managed than large fragments (LCA). Crown closure was $73 \%$ in the LCA plots, and $60 \%$ in the SCA plots (Hundera et al., 2013b), with very low variation within each category. Average crown cover was $73 \%$ in the LCA plots and $61 \%$ 

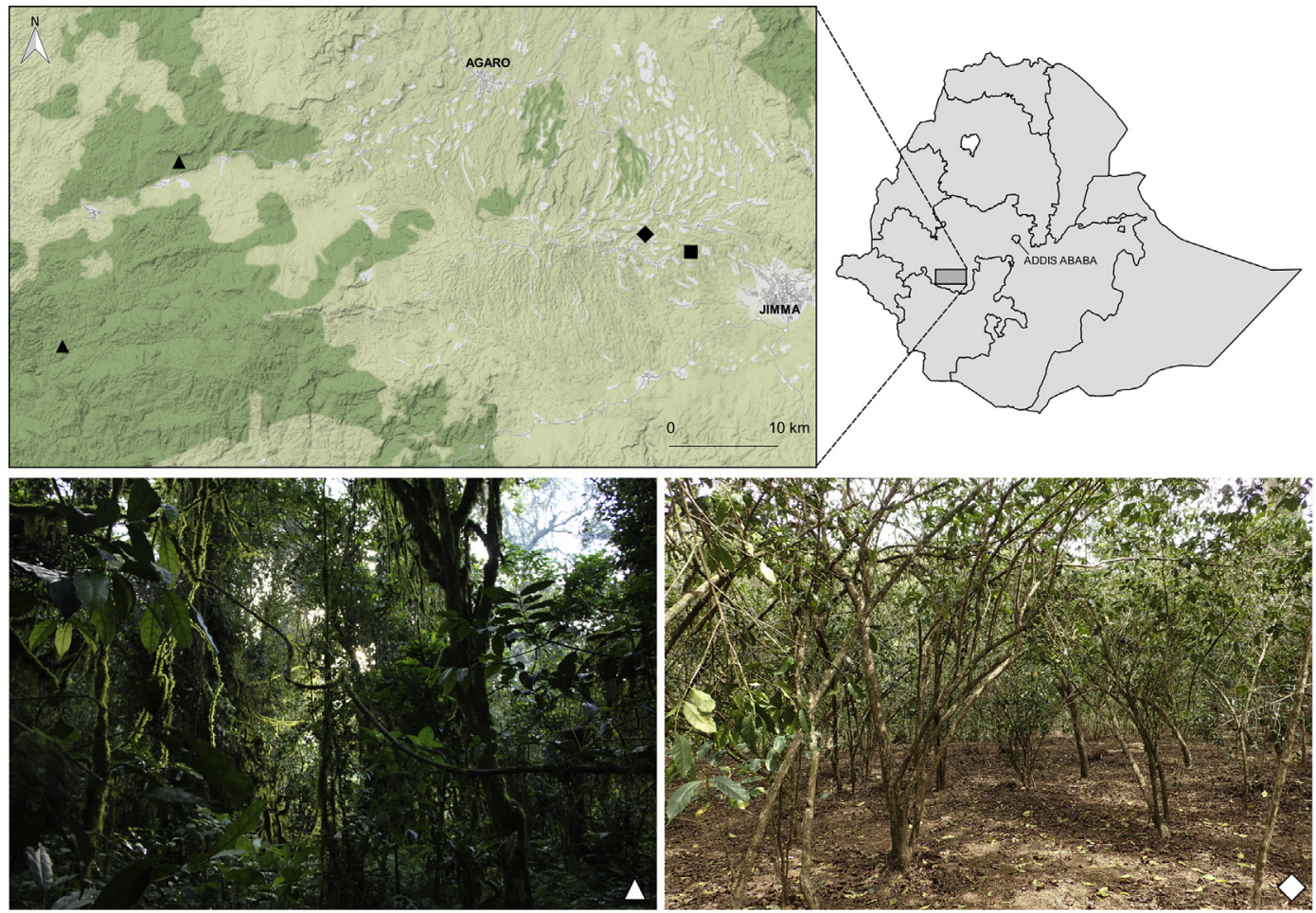

Fig. 1. Map of Ethiopia, indicating location of the studied coffee production systems ( $\triangle$ : natural coffee forest (NCF), $\square$ : large coffee agroforest (LCA), $\diamond$ : small coffee agroforest (SCA). Pictures give an overview of the forest structure inside the NCF and SCA systems. Pictures taken by author. Left map: Stamen Terrain-USA/ OSM $^{\circledR}$ OpenStreetMap contributors; right map: OpenAFRICA 2016 by Code for Africa.

in the SCA plots (Hundera et al., 2013b). Coffee cultivation in SWEthiopia is rainfed, no irrigation is applied. The regional differences in amount of rainfall within our study area are negligible.

\subsection{Coffee quality}

Within each plot, $6 \mathrm{~kg}$ of fresh red ripe coffee berries were collected from 25 randomly selected $C$. arabica shrubs. All berries were harvested during the peak harvest period of September-October 2012. To maintain uniformity, all harvested coffee berries were subjected to sorting by size and quality by the same person; under and over ripe berries, and berries that were abnormally small or large were discarded (3-5\% loss per sample). The wet method of coffee processing was employed (Clarke, 1985). The berries were manually pulped using a small scale drum pulper with a capacity of $45-50 \mathrm{~kg}$ berries per hour. The pulped samples were allowed to ferment in separate 151 buckets for $24 \mathrm{~h}$ before they were washed manually. After washing thoroughly, the beans were soaked for six hours in clean water. The samples were then sundried separately on a raised mesh wire. During midday, night time and early in the morning, the samples were covered with plastic sheets to avoid parchment cracking and moisture regain, respectively. After this process, we obtained approximately $1 \mathrm{~kg}$ dry, clean, green coffee beans per sampling plot.

The coffee beans were then used for evaluation of organoleptic attributes following the procedures of the Specialty Coffee Association of America (SCAA) by a panel of Q-grade SCAA-certified professionals of Efico, a coffee trading company in Belgium (SCAA, 2015). Each coffee sample was evaluated by three certified cuppers. To avoid bias, samples were presented randomly and identities of the samples were not known to the panel of cuppers.

After roasting and grounding, fragrance of the dry coffee ground and aroma of the wet coffee ground (after infusion with water) were evaluated. As an evaluation of the beverage itself, the quality of following taste attributes was scored: flavor, aftertaste, acidity, body, balance, sweetness, clean cup and uniformity. Furthermore, a score was given for the overall taste experience ('overall appreciation') of the sample as perceived by each individual cupper, and specific negative aspects in taste or aroma were identified and scored as defects. Cup quality tests were performed on an infusion prepared with $12 \mathrm{~g}$ roasted and ground coffee in $250 \mathrm{ml}$ water. Each cupper evaluated five cups of coffee infusion for each sample. Rates were given from 0 (very poor) to 10 (outstanding) (Table A.2). Finally, a consensus score for the organoleptic quality was calculated for each sample by summing up all abovementioned quality attributes and subtracting the defect score. The consensus score is rated from 0 to 100 and samples with a consensus score of 80 and above are considered specialty coffee by the SCAA (SCAA, 2015).

\subsection{C. arabica genotypes and environment}

Potential confounding effects of genetic variation of the coffee shrubs on coffee taste were controlled for by determining the genotype of each sampled shrub. We used the procedures outlined in Aerts et al. (2013) and Berecha et al. (2014) and genotyped green leaves from all shrubs from which berries were obtained, on 24 SSR loci (Table A.3). We then performed a hierarchical analysis of molecular variance (AMOVA), in order to obtain the molecular variance (MV) and an among-population genetic differentiation $\left(\Phi_{P T}\right)$ matrix. Based on the $\Phi_{P T}$ matrix, we performed a principal coordinates analysis (PCoA) with varimax rotation in order to reduce the dataset's multidimensionality. Both the AMOVA and PCoA were performed in GENALEX 6.503.

Elevation of each study plot was measured using a GPS (Garmin Oregon ${ }^{\circ} 450 \mathrm{t}$ ) (Table A.1). In each plot, seven soil samples were randomly collected to quantify chemical characteristics for composite topsoil samples (Table A.4). The samples were taken at 0-30 cm depth using an auger, and were pooled and thoroughly mixed to yield one composite soil sample per plot. Following soil characteristics were analyzed: soil acidity, electrical conductivity, available boron, available phosphorous, available potassium, cation exchange capacity, exchangeable calcium, exchangeable magnesium, exchangeable sodium, 

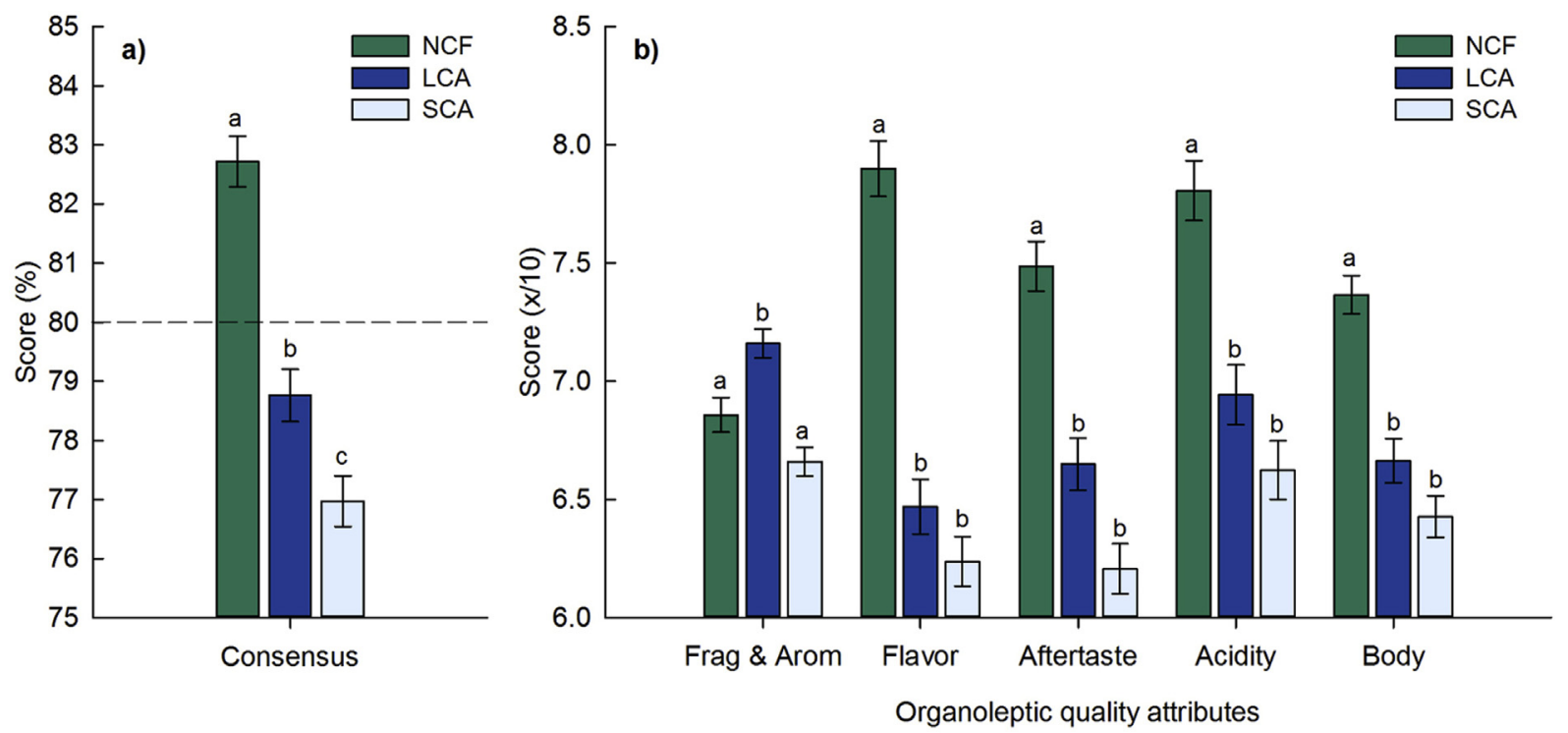

Fig. 2. Influence of forest management intensity (NCF: natural coffee forest, LCA: large coffee agroforest, SCA: small coffee agroforest) on Arabica coffee organoleptic quality in SW Ethiopia. (a) Estimated marginal mean \pm SE of the quality consensus score, valued on a 100-point scale. Only coffee with a consensus score of 80 points (indicated by a dashed line) or above can be considered Specialty Coffee. (b) Estimated marginal means \pm SE for the individual quality attributes, valued on a 10-point scale. For each organoleptic quality attribute, different letters indicate significant differences between the three forest management intensities. All pairwise $P$-values $<0.001$, except bc for Consensus $(P=0.003)$, and ab for Frag \& Arom $(P(\mathrm{NCF}-\mathrm{LCA})=0.015)$. Identical letters per quality attribute indicate nonsignificant differences: aa for Frag \& Arom $(P=0.171)$, bb for Flavor $(P=0.805)$, bb for Aftertaste $(P=0.119)$, bb for Acidity $(P=0.106)$, and bb for Body $(P=0.154)$. Estimated marginal means and $P$-values can be found in Table A.9.

exchangeable potassium, organic carbon percentage, total nitrogen percentage, and following micro nutrients: manganese, iron, copper, and zinc. Soil chemical analysis was performed at the National Soil Analysis Laboratory in Addis Ababa, Ethiopia. Principal components were extracted from the determined soil chemical characteristics by use of the 'rda' function of the 'vegan' package (Oksanen et al., 2016; R Core Team, 2016). Prior to principal component analysis (PCA), all soil variables were standardized using the generic 'scale' function in $R(R$ Core Team, 2016).

\subsection{Data analysis}

To assess the effect of forest management intensity (factor) on the organoleptic coffee quality attributes (response variables), we used generalized linear mixed models (GLMM). We used the beta probability distribution and a logit link function to model the non-normal, continuous, non-negative, right-skewed coffee quality attributes. As plots were clustered in nine forest fragments, fragment identity was included as a random factor in these models. We controlled for potential confounding effects of genetic variation of the coffee shrubs and for potential confounding effects of variation in elevation and soil chemical characteristics by including the corresponding variables as factors in the full models. Full models for each quality component included following factors: forest management intensity, elevation, the first three PCo axes (genetic data; Table A.5), and the first three PC axes (soil data; Table A.6). Because of the extremely high degree of association between canopy crown cover and closure on the one side, and management intensity on the other, both crown variables where not included in the models, but rather seen as implicit variables characterizing one of the three management categories. We reduced the full models based on backward model selection until only statistically significant factors remained, given that the AIC value of the reduced model did not increase by more than one compared to the AIC value of the corresponding full model (Table A.7). Differences in coffee quality scores between the three forest management intensities were evaluated by calculating the estimated marginal means (EMM) that adjust the factor level means for observed variation in the continuous covariates. Pairwise comparisons of the EMM values between the three coffee production systems (NCF, LCA, SCA) were corrected for increased type-I error by applying the Tukey method for comparing a family of three estimates.

Potential differences in mean genetic diversities, elevation, and soil chemical characteristics between the three coffee production systems were analyzed by use of one-way Analysis of Variance (ANOVA) tests (parametric variables) and Kruskal-Wallis tests (non-parametric variables). We used the Tukey's Honestly Significant Difference (HSD) Test and Dunn's Multiple Comparison Test to further investigate significant outcomes of the ANOVA and Kruskal-Wallis tests respectively. Pairwise comparisons were corrected for increased type-I error by applying the Tukey method (Tukey's HSD test) or the Benjamini-Hochberg method (Dunn's test).

We performed all analyses in $\mathrm{R}$ version 3.2.5 (R Core Team, 2016). Model assumptions were validated and all models were performed with the 'glmmTMB' package (Magnusson et al., 2017). Prior to GLMM analysis, we standardized all continuous factors using 'scale', a generic function in R. At first, only main effects and an intercept were entered in the models. For the consensus score, we also entered an interaction effect between forest and other factors in case other factors would have a significant main effect on the consensus score. Pairwise comparisons and EMM values were calculated via the 'Ismeans' package (Lenth, 2016).

\section{Results}

The coffee quality consensus score was significantly affected by forest management intensity and genetic variation of the coffee shrubs (Table A.8). No significant interaction effect was found between forest management intensity and genotype. The EMM consensus score for NCF coffee samples $(82.8 \pm 0.5)$ was significantly higher than the EMM consensus score for LCA samples $(78.8 \pm 0.5 ; P<0.001)$. The EMM consensus score for SCA samples $(76.8 \pm 0.5)$ was significantly lower than the NCF $(P<0.001)$ and LCA $(P=0.003)$ coffee samples (Fig. 2a; Table A.9). Importantly, unlike the wild coffee, sampled in NCF plots, EMM consensus scores of cultivated coffee, sampled in LCA and SCA plots, did not reach the 80-points benchmark to achieve the SCAA 
Specialty Coffee status.

The quality attributes 'balance', 'sweetness', 'clean cup' and 'uniformity' did not show variance among the studied plots, and no defects were found (Table A.2). 'Overall appreciation' was not analyzed individually due to the strong correlation with 'Consensus score'. All remaining quality attributes (fragrance and aroma, flavor, aftertaste, acidity, body) were significantly affected by forest management intensity (Table A.8). In addition, variation in Arabica coffee genotype had a significant effect on 'fragrance and aroma', 'flavor', 'aftertaste', and 'acidity'. A significant effect of elevation was found on 'fragrance and aroma'. Variation in soil characteristics had a significant effect on 'flavor' and 'acidity'. 'Body' was only influenced by forest management intensity (Table A.8). The EMM scores for all organoleptic attributes, except 'fragrance and aroma', were significantly higher for the NCF samples as compared to the LCA and SCA samples (Fig. 2b; Table A.9). These EMM scores were also all lower, however not significantly different, for SCA samples compared to LCA samples. The EMM score for quality attribute 'fragrance and aroma' was significantly higher for LCA samples compared to NCF and SCA samples (Fig. 2b; Table A.9).

The molecular variance (MV) differed significantly between the production systems $\left(\chi^{2}=6.50, \mathrm{df}=2, P=0.039\right)$, with a significantly lower mean $\mathrm{MV}$ in NCF $(12.55 \pm 2.95)$ compared to SCA $(17.66 \pm 3.81)$ populations $(P=0.044)$. No significant difference in MV was found between NCF and LCA (14.41 \pm 2.27$)$ populations or between SCA and LCA populations (Table A.10). The elevation differed marginally significantly between the production systems $\left(F_{2,17}=3.42\right.$, $P=0.057)$, with a significantly lower mean elevation in NCF $(1949.43 \pm 92.76)$ compared to SCA $(2038.71 \pm 14.96)$ plots $(P=0.046)$. No significant difference in elevation was found between NCF and LCA (1998.50 \pm 57.72) plots or between SCA and LCA plots (Table A.10). Following soil characteristics differed significantly between the production systems: $\mathrm{pH}\left(\chi^{2}=6.09\right.$, $\left.\mathrm{df}=2, P=0.048\right)$, available potassium $\left(F_{2,17}=4.92, P=0.021\right)$, cation exchange capacity $\left(\chi^{2}=7.21, \mathrm{df}=2, P=0.027\right)$, exchangeable sodium $\left(\chi^{2}=6.12\right.$, $\mathrm{df}=2, P=0.047)$, exchangeable potassium $\left(F_{2,17}=4.18, P=0.033\right)$, and copper $\left(F_{2,17}=5.19, P=0.017\right)$ (Table A.10).

\section{Discussion}

This study is the first to assess the effects of general forest management intensity on C. arabica organoleptic quality in SW Ethiopia, the only place where $C$. arabica grows naturally. Controlling for coffee genetic variation, and variation in elevation and soil chemical characteristics, we showed that boosting Arabica coffee yield through forest management intensification negatively affects the organoleptic quality of the coffee produced. This indicates a trade-off between quality and quantity of Coffea arabica yield in the studied coffee production systems in SW Ethiopia. Importantly, only the coffee samples from the NCF systems attained the SCAA Specialty Coffee label. Through the removal of canopy trees and understory vegetation, forest management for coffee production induces a spectrum of interacting changes to the local habitat and the cultivated coffee shrubs. Whereas our data do not allow to pinpoint the exact mechanisms that mediate decreasing coffee cup quality through management intensification, in what follows, we discuss possible explanatory factors that would require a further in-depth investigation.

Forest management intensity for coffee production, with reduced shade level as the most prominent consequence, resulted in a significant negative effect on the coffee quality consensus score. In addition to reduced shade levels, the negative effects of increasing forest management intensity on organoleptic quality can be amplified through a decreased fragment area and increased perimeter-area ratio, causing further increase in light intensity and air temperature and decrease of relative air humidity (Didham and Lawton, 1999). This confirms our expectations, as increased light and temperature conditions are known to affect the synthesis of various organoleptic quality precursors in coffee berries during maturation (e.g., sucrose, trigonelline, chlorogenic acids, caffeine), and to cause a decreased organoleptic quality (Geromel et al., 2008; Ky et al., 2001; Vaast et al., 2006). In a study in managed coffee farms in SW Ethiopia, coffee shrubs grown in full sun conditions produced beans of lower organoleptic quality (in terms of acidity, body and flavor) compared to coffee shrubs grown in shaded conditions (Bote and Struik, 2011). The light/shade conditions were experimentally created with a significant increase in light intensity and soil temperature and a significant decrease in relative air humidity when comparing the full sun conditions to the shaded conditions (Bote and Struik, 2011). Also previous studies in introduced ranges of $C$. arabica in Africa and South and Central America found a negative effect of reduced shade levels on organoleptic quality of Arabica coffee (Bertrand et al., 2012; Geromel et al., 2008; Joët et al., 2010; Vaast et al., 2006).

Similar to reduced shade levels, a lower growing altitude has been found to have negative effects on coffee quality because increased mean air temperatures accelerate the berry ripening process and hence, change the biochemical bean composition (Geromel et al., 2008; Vaast et al., 2006). Guyot et al. (1996) and Avelino et al. (2005) found a positive relation between increasing altitude and organoleptic quality for Arabica coffee cultivated in Central America. A recent study, conducted in managed coffee farms SW Ethiopia, also found an improved Arabica coffee organoleptic quality with increasing altitude (Tolessa et al., 2017). In our study, we found a significant effect of elevation on 'fragrance and aroma', but not on the consensus score.

Reduced canopy cover and understory vegetation density will also indirectly affect the coffee shrubs through changed soil mineralization processes and soil nutrient availability (Babbar and Zak, 1994; Beer et al., 1998). Variability in soil characteristics that were measured in this study had a significant effect on 'flavor' and 'acidity', but not on the consensus score. We only included PCA scores in the statistical models and did not analyze the effects of individual soil chemical characteristics. Yadessa et al. (2008) studied the influence of soil properties on cup quality of wild Arabica coffee beans grown in SW Ethiopian forests, and found a better cup quality with increased level of available phosphorus and potassium. In addition to the concentration of available nutrients in the soil, the mineral nutrient uptake capacity of the coffee shrubs is also known to be affected by the diversity and abundance of arbuscular mycorrhizal fungi (AMF) colonizing the coffee roots (Andrade et al., 2009; Smith and Read, 2008). A recent study conducted in the Jimma zone, SW Ethiopia, found that the AMF communities on coffee roots are negatively affected by increasing coffee forest management (De Beenhouwer et al., 2015b). This, and other biotic interactions that are altered as a consequence of increasing coffee forest management, could possibly affect the coffee organoleptic quality in a negative way. Recent studies conducted in SW Ethiopia already demonstrated the negative impact of coffee forest management on tree species diversity and overall forest structure (Aerts et al., 2011; Hundera et al., 2013b), epiphytic orchid species diversity (De Beenhouwer et al., 2015a; Hundera et al., 2013a), and insect pollinator communities (Berecha et al., 2015; Samnegård et al., 2014). Even though C. arabica is self-compatible, fruit set and fruit weight have been observed to increase with increasing abundance and species richness of insect pollinators (Hipólito et al., 2016, 2018; Klein et al., 2003; Roubik, 2002; Vergara and Badano, 2009). Also a reduced gene flow was found in Arabica coffee cultivated in agroforests as compared to natural coffee producing forests, indicating a reduced long-distance pollen dispersal and increased proportion of self pollination (Berecha et al., 2014). However, no studies so far have tested direct effects of pollination services on organoleptic coffee quality.

In terms of shrub management, our results showed that the consensus quality score was significantly affected by the genetic variation of the coffee shrubs. Other studies have shown that organoleptic quality may indeed differ depending on Arabica coffee genotype due to, for example, differences in caffeine content (Dessalegn et al., 2008) or due to different responses to environmental factors such as the growing 
altitude (Bertrand et al., 2006). However, it is not a given fact that genetic variation in $C$. arabica genotype will affect the organoleptic coffee quality (see Van der Vossen, 2009). In our study, we only included PC scores in the statistical models and did not analyze the individual effects of different Arabica coffee genotypes. For further discussion on differences in genetic variation of the coffee shrubs between different coffee production systems in SW Ethiopia, we refer to Aerts et al. (2013).

In other studies, also a higher fruit load has been found to decrease organoleptic quality of Arabica coffee in Ethiopia (Bote and Jan 2017) and Costa Rica (Vaast et al., 2006), due to competition among fruits for available carbohydrates (Cannell, 1985). Even though we did not quantify the fruit load in this current study, it is generally known that wild coffee shrubs in SW Ethiopian natural coffee forests have a lower fruit load compared to managed coffee shrubs (i.e., different genotype and pruned) in coffee agroforestry systems in the same area (Aerts et al., 2011; Schmitt et al., 2010). The increased fruit load of coffee shrubs cultivated in more intensified agroforests as compared to NCF systems, could therefore also contribute to the observed decrease in consensus score in this study.

\section{Implications and concluding remarks}

Unlike the wild coffee which was sampled in NCF plots, the cultivated coffee sampled in LCA or SCA plots did not reach the 80-points benchmark to achieve the SCAA Specialty Coffee status. This indicates a trade-off between quality and quantity of $C$. arabica yield in the studied coffee production systems in SW Ethiopia. Coffee that is graded Specialty Coffee is a high quality food product of important economic value on the international market (Bacon, 2005). Currently, however, price premiums are mostly generated downstream the coffee value chain, following cupping and grading by the Ethiopia Commodity Exchange. Even if in the future farmers would receive price differentiations based on quality, the very low yields of wild coffee compared to coffee agroforestry systems gives smallholder coffee farmers no option but to optimize quantity, not quality. Higher market prices for selling higher quality wild coffee cannot compete with the income smallholder farmers generate from higher yields in managed forests (Mitiku et al., 2017, 2018). Such management intensification, however, may further jeopardize the conservation of the last remaining Ethiopian wild forests (Aerts et al., 2017) and their coffee genetic resources (Aerts et al., 2013). Several projects in tropical countries have successfully improved productivity on farms while improving ecosystem functioning and delivered services such as carbon sequestration (Ponisio et al., 2015; Pretty, 2008; Pretty et al., 2006). In the case of coffee, potential techniques to increase yield quantity while reducing the intensity of forest management, hence also potentially increasing yield quality, include (i) improving the coffee shrub management (i.e., pruning techniques and cultivar selection) and (ii) increasing the diversity of coffee pollinators by increasing the density of natural nest and food resources (e.g., flowering plants in understory and canopy, including epiphytes; natural forest in near proximity of the agroforestry area). Nevertheless, there will still be a need to protect the remaining natural forests as this is the solely resource for natural coffee genetic diversity and native pollinator species.

\section{Author's contribution}

RA, OH, and GB conceived and designed the study; GB collected field data with permission of the farmers; RA and LG performed the statistical analysis; GB and LG prepared the initial draft of the manuscript. All authors contributed to interpretation of research data, to preparing, discussing and editing of the manuscript.

\section{Funding}

This research was financially supported by the Research Foundation - Flanders (FWO) and the Flemish Interuniversity Council (VLIR-UOS).

\section{Acknowledgements}

We gratefully acknowledge all farmers who allowed us to work in their coffee agroforests, and Daniel Damtew (research assistant at Jimma University) for his profound assistance during data collection. We thank Kenny Helsen (KU Leuven) for feedback on the statistical analyses and two anonymous reviewers for feedback on our manuscript.

Coffee leaf samples were collected in the framework of the Institutional University Cooperation Program of Jimma University (permit IUC-JU/725/08 of 12/08/2008) and analyzed in Belgium as requested by Jimma University's Office for Academic and Research Affairs (Ref. No. JU 51/900 of 21/01/2009). The samples are not within the scope of EU ABS regulation. Data reported in this paper are available in Appendix.

\section{Appendix A. Supplementary data}

Supplementary data to this article can be found online at https:// doi.org/10.1016/j.jenvman.2018.10.037.

\section{References}

Aerts, R., Berecha, G., Gijbels, P., Hundera, K., Van Glabeke, S., Vandepitte, K., Muys, B., Roldán-Ruiz, I., Honnay, O., 2013. Genetic variation and risks of introgression in the wild Coffea arabica gene pool in south-western Ethiopian montane rainforests. Evol. Appl. 6, 243-252. https://doi.org/10.1111/j.1752-4571.2012.00285.x.

Aerts, R., Geeraert, L., Berecha, G., Hundera, K., Muys, B., De Kort, H., Honnay, O., 2017. Conserving wild Arabica coffee: emerging threats and opportunities. Agric. Ecosyst. Environ. 237, 75-79. https://doi.org/10.1016/j.agee.2016.12.023.

Aerts, R., Hundera, K., Berecha, G., Gijbels, P., Baeten, M., Van Mechelen, M., Hermy, M., Muys, B., Honnay, O., 2011. Semi-forest coffee cultivation and the conservation of Ethiopian Afromontane rainforest fragments. For. Ecol. Manage. 261, 1034-1041. https://doi.org/10.1016/j.foreco.2010.12.025.

Andrade, S.A.L., Mazzafera, P., Schiavinato, M.A., Silveira, A.P.D., 2009. Arbuscular mycorrhizal association in coffee. J. Agric. Sci. 147, 105-115. https://doi.org/10. 1017/S0021859608008344.

Anthony, F., Combes, M.C., Astorga, C., Bertrand, B., Graziosi, G., Lashermes, P., 2002. The origin of cultivated Coffea arabica L. varieties revealed by AFLP and SSR markers. Theor. Appl. Genet. 104, 894-900. https://doi.org/10.1007/s00122-001-0798-8.

Avelino, J., Barboza, B., Araya, J.C., Fonseca, C., Davrieux, F., Guyot, B., Cilas, C., 2005 Effects of slope exposure, altitude and yield on coffee quality in two altitude terroirs of Costa Rica, Orosi and Santa María de Dota. J. Sci. Food Agric. 85, 1869-1876. https://doi.org/10.1002/jsfa.2188.

Babbar, L.I., Zak, D.R., 1994. Nitrogen cycling in coffee agroecosystems: net N mineralization and nitrification in the presence and absence of shade trees. Agric. Ecosyst. Environ. 48, 107-113. https://doi.org/10.1016/0167-8809(94)90081-7.

Bacon, C., 2005. Confronting the coffee crisis: can Fair Trade, organic, and specialty coffees reduce small-scale farmer vulnerability in Northern Nicaragua? World Dev. 33, 497-511. https://doi.org/10.1016/j.worlddev.2004.10.002.

Beer, J., Muschler, R., Kass, D., Somarriba, E., 1998. Shade management in coffee and cacao plantations. Agrofor. Syst. 38, 139-164. https://doi.org/10.1023/ A:1005956528316.

Berecha, G., Aerts, R., Muys, B., Honnay, O., 2015. Fragmentation and management of Ethiopian moist evergreen forest drive compositional shifts of insect communities visiting wild Arabica coffee flowers. Environ. Manag. 55, 373-382. https://doi.org/ 10.1007/s00267-014-0393-9.

Berecha, G., Aerts, R., Vandepitte, K., Van Glabeke, S., Muys, B., Roldán-Ruiz, I., Honnay, O., 2014. Effects of forest management on mating patterns, pollen flow and intergenerational transfer of genetic diversity in wild Arabica coffee (Coffea arabica L.) from Afromontane rainforests. Biol. J. Linn. Soc. 112, 76-88. https://doi.org/10. 1111/bij.12274.

Bertrand, B., Boulanger, R., Dussert, S., Ribeyre, F., Berthiot, L., Descroix, F., Joët, T., 2012. Climatic factors directly impact the volatile organic compound fingerprint in green Arabica coffee bean as well as coffee beverage quality. Food Chem. 135, 2575-2583. https://doi.org/10.1016/j.foodchem.2012.06.060.

Bertrand, B., Vaast, P., Alpizar, E., Etienne, H., Davrieux, F., Charmetant, P., 2006. Comparison of bean biochemical composition and beverage quality of Arabica hybrids involving Sudanese-Ethiopian origins with traditional varieties at various elevations in Central America. Tree Physiol. 26, 1239-1248. https://doi.org/10.1093/ treephys/26.9.1239.

Bote, A.D., Jan, V., 2017. Tree management and environmental conditions affect coffee (Coffea arabica L.) bean quality. NJAS - Wageningen J. Life Sci. 83, 39-46. https:// 
doi.org/10.1016/j.njas.2017.09.002.

Bote, A.D., Struik, P.C., 2011. Effects of shade on growth, production and quality of coffee (Coffea arabica) in Ethiopia. J. Hortic. For. 3, 336-341.

Cannell, M.G.R., 1985. Physiology of the coffee crop. In: Clifford, M.N., Willson, K.C. (Eds.), Coffee: Botany, Biochemistry and Production of Beans and Beverage. Croom Helm, London, pp. 108-134. https://doi.org/10.1007/978-1-4615-6657-1_5.

Clarke, R.J., 1985. Green coffee processing. In: Clifford, M.N., Willson, K.C. (Eds.), Coffee: Botany, Biochemistry and Production of Beans and Beverage. Croom Helm, London, pp. 230-250.

De Beenhouwer, M., Aerts, R., Hundera, K., Van Overtveld, K., Honnay, O., 2015a Management intensification in Ethiopian coffee forests is associated with crown habitat contraction and loss of specialized epiphytic orchid species. Basic Appl. Ecol. 16, 592-600. https://doi.org/10.1016/j.baae.2015.06.006.

De Beenhouwer, M., Muleta, D., Peeters, B., Van Geel, M., Lievens, B., Honnay, O., 2015b DNA pyrosequencing evidence for large diversity differences between natural and managed coffee mycorrhizal fungal communities. Agron. Sustain. Dev. 35, 241-249. https://doi.org/10.1007/s13593-014-0231-8.

Dessalegn, Y., Labuschagne, M.T., Osthoff, G., Herselman, L., 2008. Genetic diversity and correlation of bean caffeine content with cup quality and green bean physical characteristics in coffee (Coffea arabica L.). J. Sci. Food Agric. 88, 1726-1730. https://doi. org/10.1002/jsfa.3271.

Didham, R.K., Lawton, J.H., 1999. Edge structure determines the magnitude of changes in microclimate and vegetation structure in tropical forest fragments. Biotropica 31, 17-30. https://doi.org/10.2307/2663956.

Food and Agriculture Organization of the United Nations (FAO), 2015. Statistical Pocketbook: Coffee 2015. FAO, Rome.

Geromel, C., Ferreira, L.P., Davrieux, F., Guyot, B., Ribeyre, F., dos Santos Scholz, M.B., Pereira, L.F.P., Vaast, P., Pot, D., Leroy, T., Filho, A.A., Vieira, L.G.E., Mazzafera, P., Marraccini, P., 2008. Effects of shade on the development and sugar metabolism of coffee (Coffea arabica L.) fruits. Plant Physiol. Biochem. 46, 569-579. https://doi. org/10.1016/j.plaphy.2008.02.006

Giovannucci, D., Byers, A., Liu, P., 2008. Adding value: certified coffee trade in North America. In: Liu, P. (Ed.), Value-adding Standards in the North American Food Market - Trade Opportunities in Certified Products for Developing Countries. FAO, Rome, pp. 1-18.

Guyot, B., Gueule, D., Manez, J.C., Perriot, J.J., Giron, J., Villain, L., 1996. Influence de l'altitude et de l'ombrage sur la qualité des cafés Arabica. Plant. Rech. Dev. 3 272-283.

Hipólito, J., Boscolo, D., Viana, B.F., 2018. Landscape and crop management strategies to conserve pollination services and increase yields in tropical coffee farms. Agric. Ecosyst. Environ. 256, 218-225. https://doi.org/10.1016/j.agee.2017.09.038.

Hipólito, J., Viana, B.F., Garibaldi, L.A., 2016. The value of pollinator-friendly practices: synergies between natural and anthropogenic assets. Basic Appl. Ecol. 17, 659-667. https://doi.org/10.1016/j.baae.2016.09.003.

Hundera, K., Aerts, R., De Beenhouwer, M., Van Overtveld, K., Helsen, K., Muys, B., Honnay, O., 2013a. Both forest fragmentation and coffee cultivation negatively affect epiphytic orchid diversity in Ethiopian moist evergreen Afromontane forests. Biol. Conserv. 159, 285-291. https://doi.org/10.1016/j.biocon.2012.10.029.

Hundera, K., Aerts, R., Fontaine, A., Van Mechelen, M., Gijbels, P., Honnay, O., Muys, B., 2013b. Effects of coffee management intensity on composition, structure, and regeneration status of Ethiopian moist evergreen Afromontane forests. Environ. Manag 51, 801-809. https://doi.org/10.1007/s00267-012-9976-5.

Hylander, K., Nemomissa, S., Delrue, J., Enkosa, W., 2013. Effects of coffee management on deforestation rates and forest integrity. Conserv. Biol. 27, 1031-1040. https://doi. org $/ 10.1111 /$ cobi.12079.

International Coffee Organization (ICO), 2016. The Current State of the Global Coffee Trade. Version 14 October 2016. http://www.ico.org/monthly_coffee_trade_stats. asp, Accessed date: 29 November 2017.

International Coffee Organization (ICO), 2017a. Total Production by All Exporting Countries. Version 31 October 2017. http://www.ico.org/trade_statistics.asp? section $=$ Statistics, Accessed date: 29 November 2017

International Coffee Organization (ICO), 2017b. Country Data on the Global Coffee Trade. http://www.ico.org/profiles_e.asp, Accessed date: 29 November 2017.

Joët, T., Laffargue, A., Descroix, F., Doulbeau, S., Bertrand, B., Kochko, A. de, Dussert, S., 2010. Influence of environmental factors, wet processing and their interactions on the biochemical composition of green Arabica coffee beans. Food Chem. 118, 693-701. https://doi.org/10.1016/j.foodchem.2009.05.048.

Klein, A.M., Steffan-Dewenter, I., Tscharntke, T., 2003. Fruit set of highland coffee increases with the diversity of pollinating bees. Proc. R. Soc. B. 270, 955-961. https:// doi.org/10.1098/rspb.2002.2306.

Ky, C.L., Louarn, J., Dussert, S., Guyot, B., Hamon, S., Noirot, M., 2001. Caffeine, trigonelline, chlorogenic acids and sucrose diversity in wild Coffea arabica L. and C. canephora P. accessions. Food Chem. 75, 223-230. https://doi.org/10.1016/S03088146(01)00204-7.
Lenth, R.V., 2016. Least-Squares Means: the R package lsmeans. J. Stat. Software 69, 1-33. https://doi.org/10.18637/jss.v069.i01. https://cran.r-project.org/web/ packages/lsmeans/index.html.

Magnusson, A., Skaug, H., Nielsen, A., Berg, C., Kristensen, K., Maechler, M., van Bentham, K., Bolker, B., Brooks, M., 2017. glmmTMB: Generalized Linear Mixed Models Using Template Model Builder. https://cran.r-project.org/web/packages/ glmmTMB/index.html.

Mitiku, F., Mey, Y. de, Nyssen, J., Maertens, M., 2017. Do private sustainability standards contribute to income growth and poverty alleviation? A comparison of different coffee certification schemes in Ethiopia. Sustain 9, 246-267. https://doi.org/10. 3390/su9020246.

Mitiku, F., Nyssen, J., Maertens, M., 2018. Certification of semi-forest coffee as a landsharing strategy in Ethiopia. Ecol. Econ. 145, 194-204. https://doi.org/10.1016/j. ecolecon.2017.09.008.

Mittermeier, R.A., Turner, W.R., Larsen, F.W., Brooks, T.M., Gascon, C., 2011. Global biodiversity conservation: the critical role of hotspots. In: Zachos, F.E., Hael, J.C. (Eds.), Biodiversity Hotspots. Springer-Verlag, Heidelberg, Berlin, pp. 3-22. https:// doi.org/10.1007/978-3-642-20992-5.

Oksanen, J., Blanchet, G.F., Kindt, R., Legendre, P., Minchin, P.R., O'Hara, R.B., Simpson, G.L., Solymos, P., Stevens, M.H.H., Wagner, H., 2016. Vegan: Community Ecology Package. https://cran.r-project.org/web/packages/vegan/.

Ponisio, L.C., M'Gonigle, L.K., Mace, K.C., Palomino, J., de Valpine, P., Kremen, C., 2015 Diversification practices reduce organic to conventional yield gap. Proc. R. Soc. B. 282, 20141396. https://doi.org/10.1098/rspb.2014.1396.

Pretty, J., 2008. Agricultural sustainability: concepts, principles and evidence. Philos. Trans. R. Soc. B. 363, 447-465. https://doi.org/10.1098/rstb.2007.2163.

Pretty, J.N., Noble, A.D., Bossio, D., Dixon, J., Hine, R.E., Penning de Vries, F.W.T., Morison, J.I.L., 2006. Resource-conserving agriculture increases yields in developing countries. Environ. Sci. Technol. 40, 1114-1119. https://doi.org/10.1021/ es051670d.

R Core Team, 2016. R: a Language and Environment for Statistical Computing. https:// cran.r-project.org/.

Roubik, D.W., 2002. The value of bees to the coffee harvest. Nature 417, 708. https://doi org $/ 10.1038 / 417708$ a.

Rudel, T.K., Coomes, O.T., Moran, E., Achard, F., Angelsen, A., Xu, J., Lambin, E., 2005. Forest transitions: towards a global understanding of land use change. Global Environ. Change 15, 23-31. https://doi.org/10.1016/j.gloenvcha.2004.11.001.

Samnegård, U., Hambäck, P.A., Nemomissa, S., Hylander, K., 2014. Dominance of the semi-wild honeybee as coffee pollinator across a gradient of shade-tree structure in Ethiopia. J. Trop. Ecol. 30, 401-408. https://doi.org/10.1017/s0266467414000327.

Schmitt, C.B., Senbeta, F., Denich, M., Preisinger, H., Boehmer, H.J., 2010. Wild coffee management and plant diversity in the montane rainforest of southwestern Ethiopia. Afr. J. Ecol. 48, 78-86. https://doi.org/10.1111/j.1365-2028.2009.01084.x.

Smith, S.E., Read, J.D., 2008. Mycorrhizal Symbiosis, third ed. Academic Press, New York.

Specialty Coffee Association of America (SCAA), 2015. Cupping Specialty Coffee. http:// www.scaa.org/?page $=$ resources\&d = cupping-protocols, Accessed date: 29 November 2017.

Specialty Coffee Association of America (SCAA), 2017a. 2017 U.S. Specialty Coffee Consumption Trends. http://www.scanews.coffee/2017/11/29/2017-u-s-specialtycoffee-consumption-trends/, Accessed date: 24 January 2018.

Specialty Coffee Association of America (SCAA), 2017b. SCAA Standards. http://scaa org/?page = resources\&d = coffee-standards, Accessed date: 29 November 2017.

Tolessa, K., D'heer, J., Duchateau, L., Boeckx, P., 2017. Influence of growing altitude, shade and harvest period on quality and biochemical composition of Ethiopian specialty coffee. J. Sci. Food Agric. 97, 2849-2857. https://doi.org/10.1002/jsfa.8114.

Vaast, P., Bertrand, B., Perriot, J.J., Guyot, B., Génard, M., 2006. Fruit thinning and shade improve bean characteristics and beverage quality of coffee (Coffea arabica L.) under optimal conditions. J. Sci. Food Agric. 86, 197-204. https://doi.org/10.1002/jsfa. 2338 .

Vanderhaegen, K., Akoyi, K.T., Dekoninck, W., Jocqué, R., Muys, B., Verbist, B., Maertens, M., 2018. Do private coffee standards 'walk the talk' in improving socio-economic and environmental sustainability? Global. Eviron. Chang. 51, 1-9. https://doi.org/ 10.1016/j.gloenvcha.2018.04.014

Van der Vossen, H.A.M., 2009. The cup quality of disease-resistant cultivars of Arabica coffee (Coffea arabica). Exp. Agric. 45, 323-332. https://doi.org/10.1017/ S0014479709007595.

Vergara, C.H., Badano, E.I., 2009. Pollinator diversity increases fruit production in Mexican coffee plantations: the importance of rustic management systems. Agric Ecosyst. Environ. 129, 117-123. https://doi.org/10.1016/j.agee.2008.08.001.

Yadessa, A., Burkhardt, J., Denich, M., Gole, T.W., Bekele, E., Goldbach, H., 2008 Influence of soil properties on cup quality of wild Arabica coffee in coffee forest ecosystems of SW Ethiopia. In: Paper Presented at 22nd International Conference on Coffee Science (ASIC), Held between 14-19 September 2008, Campinas, SP, Brazil. 